\title{
Social Entrepreneur Model for Tourism Development in Kiluan Bay
}

\author{
${ }^{1}$ NOVITA TRESIANA, ${ }^{2}$ NOVERMAN DUADJI \\ 12 Jurusan Ilmu Administrasi Negara, Fisip Universitas Lampung, \\ Jalan Prof. Soemantri Brojosoemantri No.1 Bandar Lampung \\ Surel: ${ }^{1}$ novitatresiana@yahoo.co.id; ${ }^{2}$ novermanduadji@yahoo.co.id
}

\begin{abstract}
This research recommends governance-based collaborative models through the role of community groups of local community entrepreneurs. This model is created from the weaknesses of the conventional Community Based Tourism (CBT) model through the role of 3 CBT sectors (government, private, non-profit organizations) that often run independently, sporadic, non-continuous coordination, and local community involvement which often overlooked in tourism of its own territory. The implications are seen in the economic success enjoyed only by people from outside the region. This article describes Pekon Teluk Kiluan, one of the leading coastal tourist areas in Lampung Province with coastal tourism base, education, and culture. The object of study is directed to the analysis of collaborative communities as a prerequisite for the reform of tourism governance and the development of tourism management model that is not only sided with local communities but also generates positive economy, financial independence, social preservation, culture and nature (environment). The research method is done qualitatively descriptive. Data collected from private tourism, NGO, government, entrepreneur, and community group by using questionnaire technique, interview, observation, documentation, and processed by using interactive model.
\end{abstract}

Keywords: Social Entrepreneur, Local Community, Collaborative

\section{Introduction}

The commitment of local governments in tourism management is more emphasized on professional tourism management with a hope that it can have implications for the empowerment of communities in pockets of poverty around tourist areas. Previously, the context of tourism management used was mass-based logic model of centralized planning. This is certainly no longer relevant in democracy and reform era, which proved unable to promote the development of local communities.

In the choice of tourism development policy model, the position of local government usually seems dilemmatic. There is hope on the one hand to raise the original revenue of the region through the contribution of local income, job opening, and economic improvement of the community. But on the other hand, the policy model of tourism development implemented is very contrary to the purpose of development itself. The absence of multiple effects in distributing tourism resources to the region is a testament to the failure of tourism development. If tourism development failures are linked to issues of democracy and community-driven development issues, it is further away from public expectations (Tresiana and Duadji, 2017: 6).

Responding to the dilemma of local government, the research conducted by Abdillah, Damanik, Fandeli and Sumardmadji (2015: 340-341) emphasized the need for a model of tourism development aimed at improving the quality of life of local communities, not ignoring the interests of local communities, with the obligation to uphold the principle of sustainability. The above research also shows that there is a strong relationship between the perception of local people and the development of tourism. The development of community

Received: October 17, 2017, Revision: March 12, 2018, Accepted: June 04, 2018

Print ISSN: 0215-8175; Online ISSN: 2303-2499. DOI: http://dx.doi.org/10.29313/mimbar.v34i1.3141.83-92

Accredited B based on the decree No.040/P/2014, valid on February, 18, 2014 until February, 18, 2019. Indexed by DOAJ, Sinta, IPI 
perception initially showed that local people tend to have a positive attitude, but after development becomes massive and irregular, then the perception changed. Perception will be formed by the behavior of the community, mainly local people involved either directly or indirectly in the development of tourism. This is an important core cause of the failure and success of local tourism.

The idea of a community-based tourism development model (CBT) is an idea that emphasizes the need for local potential development through local institutions with the support of collaborative governance synergy, ie state, private and non-governmental organizations involved in development and tourism. The development to operations process mainly aimed at improving the economy of local communities. Nasikun (2000: 24) describes there are some basic principles of an ideal community from the idea of Community Based Tourism: 1) To distribute benefits fairly to members of the community; 2) To develop the quality of community life ; 3) To recognize, support, and develop community ownership in the tourism sector; 4) To involve community members in initiating every aspect of tourism; 5) To maintain the uniqueness of character and culture in the local area; 6) To develop community pride; 7) To ensure environmental sustainability. Whereas, the position of government, private, and NGO is synergy in its management. .

Unfortunately, the implementation of the CBT idea model still shows less than optimal results. The results of research by Tresiana and Duadji (2017: 23-24) specifically in Kiluan Bay, Lampung Province, show trend: First, the idea of CBT with the role of three sectors in to urism management involved, ie government, NGOs and private sector is not yet integrated. The coordination occurs is sporadic and not continuous, done by the government when there is allocation of funds or by travel agents when there are guests interested in alternative tourism activities; Second, CBT in Kiluan Bay is not purely derived from community initiatives; Third, local government (village) vying to designate villages to become tourist villages, so that all villages crave appointment as a tourist village in the hope of assistance of tourism funds. In fact, it was found that government followups such as mentoring and maintenance are often unsustainable; Fourthly, NGOs cannot manage the $C B T$ intensively and continuously as it depends on the funding source of the institution itself. The Sufianti,
Sawitri, Personal and Word study (2013: 142) illustrates the cause of the unsynchronized relation among three important sectors in development is due to the lack of collaborative character which should be an integral part of communication and dialogue-based planning. Non-collaborative community characters tend to dominate power relations among the three important sectors in tourism development.

Hence in this perspective, the researcher sees no logic in the disconnection of chain of understanding of the tourism model. Community Based Tourism (CBT) model is seen as if the end result is not a process. The CBT model expected by the local community is certainly a process model that is able to create local entrepreneur bases, as well as to provide the welfare of local communities based on collaboration and reform. It is at this point that the researcher sees the importance of changing the process of tourism development that begins with the existence of collaborative local communities and entrepreneurial spirit as the basis for the formation of social entrepreneur (Certo and Miller, 2008: 267271), into the development supported by the collaborative governance (Ansell \& Gash, 2007: 67) of tourism community.

The essence of this research puts an understanding in the direction of the tourism development reform movement that demands the devolution of power from the central government to the local government, from the elite to the collaborative society, and possesses the social entrepreneurship as the most essential condition for the democratic run of tourism governance.

Ansell \& Gash (2007: 67) and Innes \& Booher (2000: 122) have several prerequisites for the creation of a collaborative process: (1) stakeholder participation in the form of citizen power as Arnstein's participation ladder (in Muluk, 2007: 19 ); (2) equality of power, manifested through dialogue that is not hindered by the boundaries of hierarchy, and a Iso mutual respect; (3) competent actors with competences in communicating, understanding substance, and having an orientation to achieve goals for the common good and consensus.

The realization of this collaborative society is a prerequisite for the birth of social practices entrepreneur in tourism development. Certo and Miller (2008: 267-271) describe social entrepreneur in 3 aspects: (1) mission in the form of social value creation with profit as indirect 
effect; (2) performance measures tracked from social costs; (3) the voluntary use of resources. Palesangi (2013: 22) describes that the social entrepreneur conducted by tourism entrepreneur has four main elements namely social value, civil society, innovation, and economic activity. The social logic of entrepreneurs in their activities uses social capital as proposed by Yustika (2006: 192), which is a resource aggregation bound to create a durable network to institute mutually beneficial relations of friendship. Burt (in Kusumastuti, 2015: 85) reinforces by seeing the close connection through association (related) to each other that becomes the strength of economic aspects and other aspects of social existence.

In the context of this paper, the researcher understands that the interrelationship of social entrepreneur and social capital is a practical effort to fulfill the basic needs of the community around tourism through the creation of social benefits by means of optimization of social capital. It is also formed by working with other people or community organizations involved and integrate wisdom local with social innovation and able to balance social and business activities in the tourism sector. The linkage between the two will be reflected in the spectrum of social entrepreneur typology that is formed in the local community as presented by Alter (2006: 78) in the following figure 1.

This study describes 2 (two) things: (1) to analyze the collaborative community of Teluk Kiluan Community as a prerequisite for the capable and ready communities in tourism management; (2) to develop a model of tourism management that does not only have alignment with the local community but also generates positive economy, distributes, and has high social responsibility. The utilization of this study is to contribute in the development of public policy science and development management oriented to democratization, engagement, and active role of local communities. It is also useful in recommending collaborative governancebased tourism models, so that the presence of social entrepreneurs is the goal and the real product of tourism governance reform.

\section{Methods}

The research location is in Coastal Tourism Kiluan Bay, especially in Pekon Kiluan Negeri, District of Kelumbayan, Lampung Province. The time of field data collection is done in April-August 2017. Qualitative research method is descriptive. The data collected relates to collaborative communities (participation, competence and equity), potential of social capital, potential of tourism (institutional) actors, and potential of tourism management (perceptions). Primary and secondary data sourced from: (1) private tourism elements, (2) government, (3) tourism-focused NGOs; (4) Local tourism entrepreneurs; (5) Community (religious leaders, cultural figures, community leaders, youth leaders, women figures); (6) Teluk Kiluan community ( 110 people). Data collection was done by determining the informant purposively. Collection techniques are conducted by: (1) Observation; (2) In-depth interviews: (3) Documents (4) Questionnaire and (5) FGD. The data were collected, then analyzed using qualitative analysis following the interactive model procedure from Miles and Huberman (1992: 132), whose steps were: (1) data collection; (2) data interpretation; (3) data presentation; and (4) conclusions.

\section{Description of Tourism Potential and Needs in Kiluan Bay, Lampung Province}

Teluk Kiluan is a small bay that is part of Semangka Bay of Lampung Province

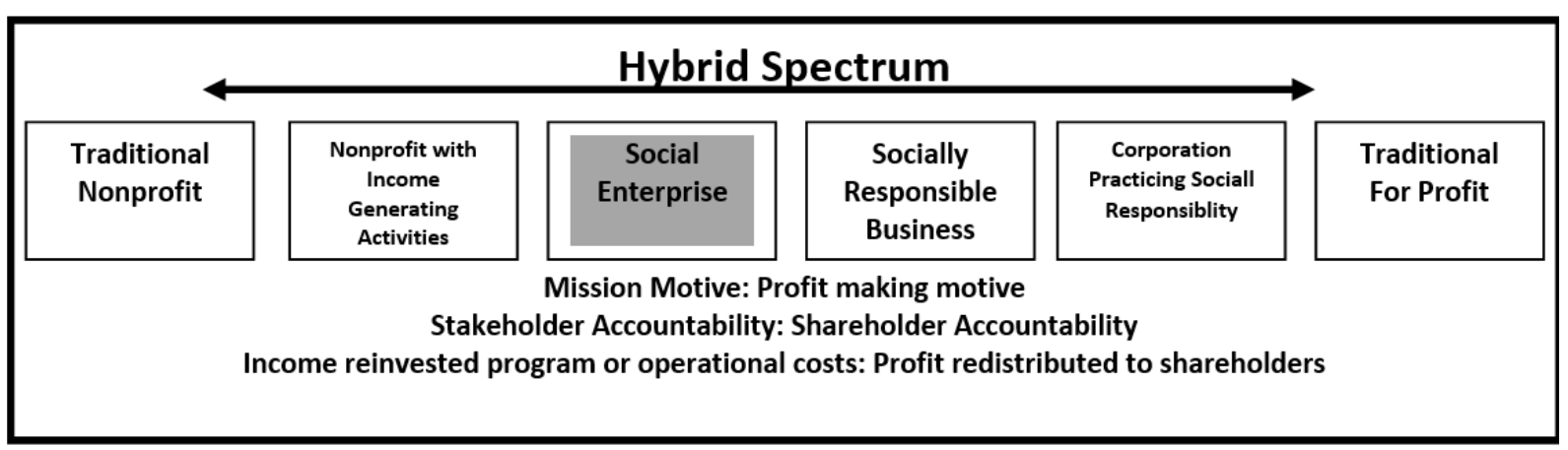

Figure 1. Typology of Social Entrepreneurs 
and is one of the leading tourist areas (KWU). Administratively, its position is in Pekon (Village) Kiluan Negeri, Kelumbayan District, Tanggamus District. Referring to the Master Plan of Tourism Development of Lampung Province 2012-2031 reflected the development of natural ecotourism activities based on coastal nature conservation. 8 points of coastal attractions are identified near the Superior Tourism Area (KWU) Teluk Kiluan besides other tourism potentials, such as Karang Bebay, Coconut Island, Cikal Negeri, Curup Hasang, Goa Semedi. The main issues and themes of tourism product development in KWU Teluk Kiluan are coastal ecotourism with dolphin attractions, surfing, boating, sunbathing, and mangrove forest.

Tourism potential is seen from the number of visitors of Teluk Kiluan for 9000 11.000 visitors per year, or an average of 10,000 visitors per year. Potential and economic value of that place can be described as follows: (1) tourism facilities and infrastructure is still minimal, ranging from the access road to Teluk Kiluan, availability of electricity, toilets, mobile signals, hygiene facilities, and the availability of stalls. There is still much to be improved and provided, ranging from mosques, homestays, rafting, security posts, safety posts, toilets, mobile towers, signboards, gazebo, and the addition of several water attractions; (2) based on interviews with managers, the average number of visitors per year is 10,000 people, the total value of Teluk Kiluan economy is Rp 7.900.000.000 per year. The economic value of the Kiluan Bay tourism service is large enough that it needs to be well managed and expected to prosper the local community (Tresiana and Duadji, 2017: 32).

Based on questionnaires and interviews performed, the needs and expectations of the community related to Teluk Kiluan tourism are 1) Economic dimension, in the form of an and equitable income of all actors (especially the community), creating employment opportunities especially for local communities, increasing job opportunities/ job diversification; 2) ecological dimension, in the form of waste management and reduction of energy by saving raw material usage, priority of product development, and service of environment based and environmental awareness raising with conservation requirement; 3 ) social dimension, in the form of stakeholder involvement in planning

Table 1

Public Perception of Tourism Management in Pekon Teluk Kiluan

\begin{tabular}{clccc}
\hline \multirow{2}{*}{ No } & \multicolumn{1}{c}{ Query } & Number of & Answer Answer \\
respondents & yes & No \\
\hline 1 & What is covered by the existing tourist activities & 102 & 0 & 102 \\
2 & $\begin{array}{l}\text { Is informants agree that further tourism development has } \\
\text { done in this area }\end{array}$ & 102 & 102 & 0 \\
3 & Developed tourism should be dominated by the community & 102 & 100 & 2 \\
\hline
\end{tabular}

Source: Research Data Processed, Year 2017

Table 2

Collaborative Society of Teluk Kiluan

\begin{tabular}{|c|c|c|}
\hline $\begin{array}{c}\text { Level of Participation } \\
\text { (High) }\end{array}$ & $\begin{array}{c}\text { Level of Equality of Power } \\
\text { (High) }\end{array}$ & $\begin{array}{c}\text { Level of Local Actors } \\
\text { Competence } \\
\text { (High) }\end{array}$ \\
\hline $\begin{array}{l}\text { Involvement in musrenbangdes } \\
\text { (local deliberation) and } \\
\text { community meetings discussed } \\
\text { the sustainability of tourism } \\
\text { and local groups / institutions }\end{array}$ & $\begin{array}{l}\text { Percentage of the population } \\
\text { graduated from low-middle } \\
\text { school } \\
\text { (elementary, junior and } \\
\text { senior high schools), local } \\
\text { institutions, community groups; } \\
\text { existence and life of a group of } \\
\text { companions; local institutions } \\
\text { are able to dominate decision- } \\
\text { making, although the } \\
\text { government remains dominant }\end{array}$ & $\begin{array}{l}\text { Already controlling the media, } \\
\text { setting up tours, have begun } \\
\text { to encourage the community to } \\
\text { take a role in tourism, propose } \\
\text { programs to the government } \\
\text { and start negotiating with } \\
\text { private actors }\end{array}$ \\
\hline
\end{tabular}

Source: Research Data Processed, Year 2017 
to evaluation, improvement of community ability in tourism service management, empowerment of local institution in making tourism development decision, strengthening of local community position to outside community, guarantee of rights in exploiting and management of tourism resources, and fair play rules in the operation of tourist services; 4) cultural dimension, in the form of acceptance of contacts and cultural differences and cultural appreciation of local communities..

The potential of public perception in management of Pekon Teluk Kiluan tourism is positive for tourism management and supported by active tourism institute, such as: NGO Cikal, Management of Ecotourism Group, Community Monitoring Group, Tourism Awareness Group (Pokdarwis), Local Entrepreneurs Group.

\section{Collaborative Communities of Teluk Kiluan: Prerequisites for Social Entrepreneurs}

Prerequisites required for the realization of a collaborative society in tourism management of Kiluan Bay should be owned, so that collaborative processes do not produce democratic pseudo but democratic changes that benefit local communities. There are several prerequisites for the creation of a collaborative society: 1 ) support for participation, equality of power and competent actors; 2) social capital support owned by the community.

Based on the results interviews, observations, and FGDs, table 2 above depicts the character of the collaborative community of Teluk Kiluan. The tourism community of Kiluan Bay is classified as a collaborative society. The result of the data was found that local actors' ability based on local institutions has been able to encourage the community through transactive planning to take a role in tourism. Some of the roles that the local community has undertaken are: 1) proposing some tourism programs to local governments; 2) starting to negotiate with private actors in a matter of route, equipment, cost, cultural tourism package and services, supporting facilities and infrastructures; 3 ) as owner and manager of homestay, rental of tour equipment, guide, selfie service, and owner of several restaurants; 4) preserve the environment and empower local communities. The dominance of local communities has put
Kiluan Bay in a collaborative society position.

Furthermore, the collaborative community of Teluk Kiluan is also reflected on the social capital owned by the community in the form of: 1) Trust and solidarity: trust of people from different social, economic, cultural status, local government officials, mutual cooperation activities; 2) Collective action and cooperation, such as: implementation of religious activities (tahlilan, marriage, burial, reading al qur'an/pengajian), clean the village/environment, participate in building public facilities, Siskamling (securing the environment), Posyandu (activity held by women activists to support family's health and babies in particular); 3) Information and communication in the form: TV, Mobile, electricity, (but not yet optimal), and access to remote area that can be passed by 2-wheel vehicles; 4) Groups and networks, such as: Citizen groups, regular social gathering/ Arisan, Trade group, Youth group, Water keeper (Interview and Observation, 2017).

Social capital is the value of tourism drivers. It found the trust and solidarity between people with different cultures; collective action and cooperation through routine religious, security, social, health and cultural activities; already built information, communication, and networking. Fukuyama's research (2002: ix) through the results of his studies in various countries finds the role of social capital as the facilitation of collective action. In the context of tourism, social capital is emphasized on the togetherness of local communities and business actors to improve the quality of life together and make better changes and adjustments on an ongoing basis. The Kiluan Bay social capital cycle begins with the initial inclusion of social capital by social entrepreneurs. Furthermore, there is an increasing network of trust and cooperation which opens the access to physical development, financial aspect, and human resources. When the business unit is formed (organizational capital) and social enterprises start to benefit, then more and more social facilities will be built.

Thus, the collaborative process can be realized in communities with high levels of community participation, as well as supportive leadership. Conditions found in the Kiluan Bay community serves as the basis for ensuring the sustainability of the next set of processes, ie toward a process that brings stakeholders both public and private, into a forum with public institutions and engages in consensus- 
oriented decision making (Ansell and Gash, 2007: 81). It also brings efforts to build communication with stakeholders to realize a solutive strategy, to empower and enhance the creativity of local communities.

\section{Local Community Based Social Entrepreneur Model}

The existence of the collaborative community character of Teluk Kiluan becomes the prerequisite of the birth of social entrepreneur practice in tourism development. Social entrepreneurs are entrepreneurial ideas in the management of tourism managed by local communities, which are usually local entrepreneurial groups, aimed at the economy as well as assisting and solving community issues. In the context of social entrepreneur, tourism potential of Kiluan Bay is seen as an opportunity to form a new business (entrepreneur) that is beneficial to the surrounding community. The result to be achieved is not only the material advantage or the satisfaction of tourists but also how the idea put forward to give a positive impact and positive resolution for community's problems. Social entrepreneurs' requirement is not a given, but a social value creation process that is formed by working with other people or collaborative governance organizations, and usually implies economic activity.

The development model of Teluk Kiluan tourism through CBT is expected to boost tourism potentials and local communities through local institutions, from the early stages of development to operations aimed at improving the economy of local communities and resolving social needs issues. Active presence tourism institutions with potential for the growth of social entrepreneurs are ranging from NGOs, ecotourism management groups, community watch groups, awareness groups, and local tourism entrepreneur groups. Based on observations, interviews, and documentation, a map of strengths and weaknesses of local institutions based on social entrepreneurs in Teluk Kiluan is shown in Table 3.

Tables 3 and 4 illustrate a communitybased tourism management model (CBT) run by 3 sectors that work together, synergize, and deal with the strengths and weaknesses of the public sector/government, the private sector/business sector, the NGO sector, and the community sector. Each institution has weaknesses that require solutions and collaborative governance in tourism management. The strategic issue is that there is a need for a choice of tourism management that has different character, has a social entrepreneurship with a strong mission, and should be able to earn their own income to be independent from government and private donations. The role of 3 other sectors (government, private, non profit organizations) is needed and desirable, but social entrepreneurs conducted by tourism management entrepreneurs with orientation to and based on local community become strategic choice for Teluk Kiluan tourism development model.

Palesangi (2013: 22) states that social entrepreneur model conducted by tourism entrepreneur has four main elements of social value, civil society, innovation, and economic activity. Economic activity is a balance between social and business or economic activity in order to ensure the independence and sustainability of the organization's social mission. Social value is the most distinctive element that refers to the creation of tangible social benefits for society and the environment. Civil society comes from civil society initiative and participation by optimizing social capital in society. Meanwhile, innovation is to solve social problems in innovative ways, including combining local wisdom with social innovation.

Based on interviews, documentation, and observations processed by the researcher, it is found that entrepreneurial communities within the Teluk Kiluan tour group have already acquired: (1) social value, local entrepreneur groups consisting of various community elements ranging from customary/cultural figures, youth, entrepreneurs who have been able to create local community-based business with attention to the development of local culture, ranging from homestay, rental service, guide service, cultural tourism, educational tours and other accommodation; (2) Civil society in the form of collective action and cooperation through local institutions, trust and solidarity become the basis of collective action; (3) innovation, tourism system has a cooperative, profit sharing system, innovation welcoming tourists, sanitation system; (4) economic activity, producing tourism products ranging from natural tourism packages, cultural tourism, educational tours, culinary, and souvenirs.

By using Hybrid Spectrum frame from Alter (2006: 78), it is depicted the typology 
Table 3

Map of Strengths \& Weaknesses of Conventional CBT Sector in Tourism Management

\begin{tabular}{lll}
\hline \multicolumn{1}{c}{ Sector } & \multicolumn{1}{c}{ Strengths } & \multicolumn{1}{c}{ Weaknesses } \\
\hline The role of NGOs & $\begin{array}{l}\text { Having access to domestic and } \\
\text { overseas donors/sponsors; Knowledge } \\
\text { of community development }\end{array}$ & $\begin{array}{l}\text { Rely on donors; Maximum role in } \\
\text { liaison rather than field executor }\end{array}$ \\
$\begin{array}{ll}\text { The Role of Society } \\
\text { (Community) }\end{array}$ & $\begin{array}{l}\text { Ability to cultivate community potential } \\
\text { and environmental guard, resource } \\
\text { owner, and reliable field executive }\end{array}$ & $\begin{array}{l}\text { Must be supported by strong local } \\
\text { institutions and strong social capital, } \\
\text { the paradigm of tourism activities } \\
\text { tend to be non-profit } \\
\text { Private Role }\end{array}$ \\
$\begin{array}{lll}\text { High marketing and managerial } \\
\text { capabilities; Determining effective } \\
\text { goals and strategies for profit-seeking } \\
\text { motives }\end{array}$ & $\begin{array}{l}\text { Less involving the community, } \\
\text { the scale is still small due to less } \\
\text { attractive economically }\end{array}$ \\
$\begin{array}{ll}\text { Able to organize large programs; } \\
\text { Ability to set policies/regulations; Pro } \\
\text { against the welfare of society. }\end{array}$ & $\begin{array}{l}\text { The centralistic approach; Decisions } \\
\text { taken may benefit certain parties } \\
\text { and harm others; Complicated } \\
\text { bureaucracy }\end{array}$ \\
\hline
\end{tabular}

Source: Research Data Processed, Year 2017

\section{Table 4 \\ Management Group, Function, and Institutional Orientation of Teluk Kiluan Tourism Management}

\begin{tabular}{|c|c|c|}
\hline $\begin{array}{c}\text { Management } \\
\text { Elements }\end{array}$ & Function & $\begin{array}{l}\text { Orientation } \\
\text { Institutional }\end{array}$ \\
\hline Local Institutions & $\begin{array}{l}\text { As the main manager, while the government and tourism } \\
\text { actors as partners. All are involved and complement each } \\
\text { other's deficiencies so that management becomes unified and } \\
\text { integrated. Community empowerment is done through local } \\
\text { community institutions. The weakness of this management } \\
\text { element is a weak local community institution in tourism } \\
\text { management }\end{array}$ & $\begin{array}{l}\text { Community- } \\
\text { based }\end{array}$ \\
\hline Tourism Actors & $\begin{array}{l}\text { Tourism actors are the main managers, while the community } \\
\text { and government are partners. The weakness is that the } \\
\text { community becomes the object of commodification, the } \\
\text { community empowerment is relatively small, and there } \\
\text { is a potential conflict between the tourism actors and the } \\
\text { community. }\end{array}$ & Business \\
\hline Government & $\begin{array}{l}\text { Management may be a state-owned enterprise. The } \\
\text { weaknesses are limited community participation, low } \\
\text { benefits enjoyed by the community, and the community has } \\
\text { difficulties in exercising the control }\end{array}$ & Structural \\
\hline $\begin{array}{l}\text { Actors of } \\
\text { Entrepreneurial } \\
\text { Tourism }\end{array}$ & $\begin{array}{l}\text { Presents a blend of local social institutions, tourism, and } \\
\text { government actors. One of the dominant elements (the } \\
\text { community) in the management of tourism and other } \\
\text { elements involved according to their respective roles are } \\
\text { mutually agreed }\end{array}$ & $\begin{array}{l}\text { Professionalism, } \\
\text { partnership } \\
\text { (community, } \\
\text { government, } \\
\text { private) \& social } \\
\text { responsibility }\end{array}$ \\
\hline
\end{tabular}

Source: Research Data Processed, Year 2017

of social entrepreneur of Belel Kiluan which is located at the intersection, between non-profit and pure business organization. Emerging trends and shifts in social entrepreneurs are initially considered to be non-profit activities into business-oriented activities. Typology of social entrepreneurs initially was as a local entrepreneurial group in Kiluan Bay which purely an entrepreneurs business that only engaged in social, especially in the development of Teluk Kiluan culture. Social entrepreneurs have a core of voluntary community empowerment. Profit does not become the main objective, even if there is, it is not a main goal and the value can be considered small because the main core of 
empowerment is for the common good. In next development, social entrepreneur of Teluk Kiluan experienced a shift, which was originally considered non-profit activities into business-oriented activities. Social Entrepreneur of Teluk Kiluan became a business with the empowerment of society financially. It was not only generated welfare for the poor community but also bring financial benefits. Dozens of residents' homes in Kiluan Bay transformed into homestay, boat rentals, and small boat tours which absorbed many labors, grew micro-enterprises that based their activities on sights and at home (culinary and souvenir), and formed cooperatives from local community capital.

The description of the social entrepreneur development model of Teluk Kiluan tourism is illustrated below.

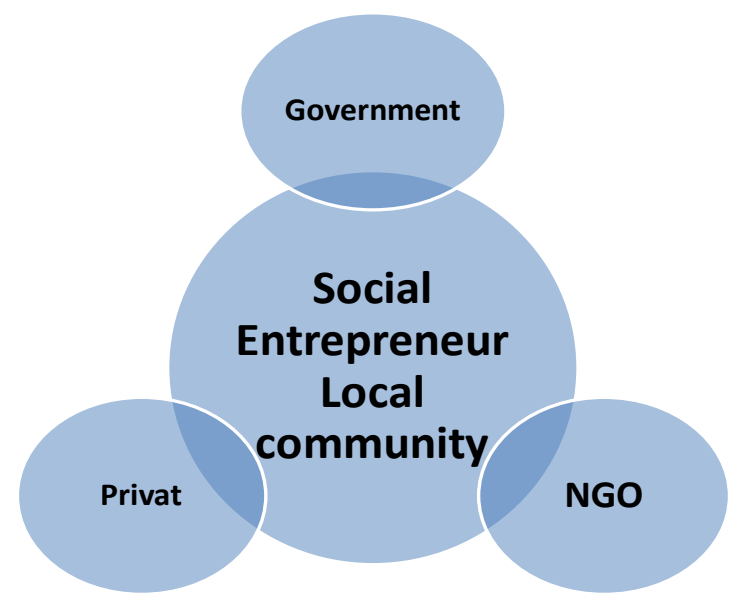

Figure 2

Local Community's Social Entrepreneur Model in Teluk Kiluan

Figure 2 is a model of Teluk Kiluan Social Entrepreneurs composed of 3 aspects: voluntary sector (NGO), public sector (government) concerning public interest, and private sector (private) which is the personal element concerned; elements of interest profit can also be included in the list. Referring to the four institutions of tourism managers, the presence of local entrepreneurial synergies based on local communities in Kiluan Bay is a strategic value of the social entrepreneur model. Social entrepreneurs of local communities have positions of other 3 sectors but they are in the midst of being the primary managers who are expected to rely on income, access government, and NGO donations or private donations. The main managers are from tourism entrepreneurs who are local communities and prioritize the interests of local communities, establish networks in relation to government, private, and NGOs, as well as to build a business through the development of tourism in the village.

Based on FGDs, the synergy of local entrepreneurship management agencies with other three sectors is as follows:

Firstly, the social entrepreneur institution ensures that tourism businesses launched by other sectors can be financially sustainable and support the village's vision and mission in an effort of prospering the community, preserving the local culture, and maintaining the integrity of the beautiful environment. This sector must ensure that its efforts maintain the natural and social sustainability of the community. Without a sustainable nature, the main attraction of tourism will be destroyed. This sector should also appreciate the uniqueness and authenticity of the local social culture, protect the traditional values of cultural heritage, and contribute to cultural understanding and tolerance by visiting people. It must also ensure the economic viability of its business for a long term.

Secondly, the non-profit/nongovernmental sector plays an active role in creating and maintaining network sustainability among tourist villages, and networking between tourist villages and outsiders. Nevertheless, the main focus of social entrepreneur is the ability to be independent in operational and financial. Therefore, the NGO sector takes a strategic role for advocacy, consultancy, and facilitation for entrepreneurs and village communities extensively.

Thirdly, the government sector acts as an initiator, catalyst, and mentor in tourism development. The government has a strategic role as a policymaker that can benefit the tourism organizers. Since the social entrepreneurs' model is a legally separate business unit of other sectors, the government needs to take strategic steps to make it easier to achieve the goal. For example, there is a relief for the establishment of cooperatives or business entities engaged in the field of communitybased tourism. The government can assist the construction of main infrastructure of access to tourist villages. In addition, the government can also provide tax facilities and stimulation in the form of subsidies or allocation of funds for the development of 
tourism entrepreneurs or business groups that are really based in the village. However, the government should ensure transparency in terms of both procurement and the use of aid, including disseminating both elements to the community. It is emphasized that aid from the government can be as a starting capital or as a stimulus, but the independence of the institution's efforts is a goal to be achieved.

Fourthly, the private sector has a role of a liaison with the outside world, especially in terms of financial and marketing. Increasingly big companies that promote Corporate Social Responsibility (CSR) can be a means to gain networking, stimulus funds for certain projects, and visitors who want to spend their vacation while dedicating themselves in the community. Strategic steps that can be taken by this sector are to make database and market packages of tourist villages which attract tourists.

The synergy of the institution results in the management of Teluk Kiluan tourism which is synergic, sustainable, and continuously growing. The impact of social entrepreneurs can be seen from both internal and external aspects. Internally, it breaks the level of dependence on outsiders (private) and creates a sense of confidence. Externally, social entrepreneurs play a role as providing jobs for people who have no work yet. Santosa (2007: 35) unravels that social entrepreneur also plays a role in the context of broad social economic development, including: First, able to create new creations and innovations on the production of goods or services which is needed in tourism which cannot be handled directly by the government, for example the preservation of environmental souvenirs with standards that are not rigid. Second, is creating new job opportunities and employment opportunities in various tourism activities. Third, it is raising the equality and equity of the people around the tourism welfare. Through social entrepreneurs, business people who initially only think about the achievement of maximum profits, then start thinking of equal distribution of income so that economic development becomes sustainable.

\section{Conclusion}

The Kiluan Bay community is classified by a collaborative society with high community participation, equality of power, and competence of actors as well as the support of social capital of the community and tourism institutions. The collaborative character becomes the foundation and guarantee of the sustainability of collaborative governance, towards a solutive strategy, empowering, and enhancing the creativity of local communities.

The local community entrepreneur model is Community Based Tourism (CBT) model which was implemented before. The new model emphasizes a major role for the local community entrepreneur group whose position is in the midst of being the primary manager expected to rely on income, accessing government aid funds as well as donations of NGOs and the private sector. The main managers are from tourism entrepreneurs who are local communities and prioritize the interests of local communities and establish networks in relation to government, private, and NGOs so as to build a business through the development of tourism in the village.

This study recommends a collaborative governance so that the presence of local community entrepreneurs is the goal and the real product of tourism governance reform.

\section{References}

Abdillah, Damanik, Fandeli dan Sumardmadji. (2015).Perkembangan Destinasi Pariwisata dan Kualitas Hidup Masyarakat Lokal, Mimbar, Jurnal Sosial dan Pembangunan, Vol 31 Nomor 2, Desember, pp. 339-350

Alter, S. K. (2006). Social Enterprise Models and Their Mission and Money Relationships. In A. Nicholls (ed.), Social Entrepreneurship: New Models of Sustainable Social Change, . Oxford University Press.

Ansell, C. dan Gash, A., (2007). Collaborative Governance in Theory and Practice, Journal of Publik Administration Research and Theory, 18:543-571., doi: 10.1093/ jopart/mum032 First published, November 13, 2007. Diunduh pada tanggal 28 November 2010.

Certo and Miller.(2008). Social Entrepreneurship: Key Issues and Concepts. Business Horizons 51:67-271.

Fukuyama, Francis. ( 2002). The Great Disruption. Yogyakarta: Penerbit Qalam

Innes, J.E. dan Booher, D.E. (2000). Collaborative Dialogue as a Policy Making Strategy, Institute of Urban and Regional Development UC Berkel y, IURD Working Paper, http://escholarship.org/uc/ item/8523r5zt) Diunduh pada tanggal 13 Desember 2010. 
Kusumastuti, Ayu, (2015). "Modal Sosial dan Mekanisme Adaptasi Masyarakat Pedesaan dalam Pengelolaan dan Pembangunan Infrastruktur", Masyarakat: Jurnal Sosiologi, 20 (1): 81-97.

Miles, M. dan Huberman, A.M. (1992). Analisis Data Kualitatif: Buku Sumber Tentang Metode-Metode Baru. Jakarta. Universitas Indonesia Press.

Muluk, Khairul. (2007). Menggugat Partisipasi Publik dalam Pemerintahan Daerah: Sebuah Kajian. Malang, Bayumedia Publishing

Nasikun. (2000). Globalisasi dan Paradigma Baru Pembangunan Pariwisata Berbasis Komunitas. Yogyakarta. Penerbit Fakultas Kehutanan UGM.

Palesangi, Muliadi,. (2013). Pemuda Indon esia dan Kewirausahaan Sosial. , Prosiding Seminar Nasional Competitive Advantage. Jombang. Universitas Pesantren Tinggi Darul Ulum.
Tresiana, Novita dan Duadji, Noverman. (2017). Model Pengembangan Pengelolaan Pariwisata Berbasis Komunitas (Studi di Wilayah Teluk Kiluan Kabupaten Tanggamus). Laporan Akhir Penelitian Produk Terapan (PPT) DRPM Kemenristek Dikti RI. Bandar Lampung. Unila. Tidak Dipublikasikan.

Santosa, Setyanto P. (2007). Peran Social Entrepreneurship dalam Pembangunan", Makalah dipresentasikan di acara Seminar "Membangun Sinergisitas Bangsa Menuju Indonesia yang Inovatif, Inventif dan Kompetitif ", Universitas Brawijaya.

Sufianti, Sawitri, Pribadi dan Firman. (2013). Proses Kolaboratif Dalam Perencanaan Berbasis Komunikasi Pada Masyarakat Kolaboratif, Mimbar, Jurnal Sosial dan Pembangunan Vol 29 Nomor 2, Desember, pp. 133-144

Yustika, Ahmad Erani. (2006). Ekonomi Kelembagaan: Difinisi, Teori dan Strategi. Malang. Bayu Media. 